\title{
CHARACTERS IN ESTONIAN ETHNIC HUMOUR (1890-2004)
}

\section{Liisi Laineste}

\begin{abstract}
The study provides an overview of Estonian ethnic humour over the last century (1890-2004), focusing on three periods: the end of the 19th century, the Soviet period, and the years following Estonia's regained independence. The changes in the choice of the targets of joke throughout the century are mapped and the cultural, social and political influences in jokes are discussed. The analysis showed a clear tendency towards greater variation in ethnic joke targets. Jokes are related to social reality but the relations are not universal and may differ in countries with a different cultural, political and/or historical background.
\end{abstract}

Keywords: ethnic humor, Estonian ethnic jokes, ethnic stereotypes, jokes of postsotsialist countries.

The present overview is based on a part of my MA thesis defended in September 2004. An article covering the entire thesis contents will be published shortly in the series Reetor issued by the Estonian Literary Museum.

In the context of this paper the term 'ethnic humour' refers to popular jokes (i.e. earlier humour lore which has now become obsolete) and anecdotes (from more recent sources). These two subcategories differ from each other primarily in form, being essentially the elaboration and adaptation of the same phenomenon. The overview does not entail other types of humour (e.g. nonverbal, pictorial, situation comics or everyday conversational humour), as among other similar folklore genres popular jokes and anecdotes follow strict rules of form and are easily available.

The aim of the overview is to provide a general characterisation of the role of ethnic humour in the past (a century ago) and in the present, and to briefly discuss the possible reasons behind the changes in the tradition. This analysis enables to draw conclusions about the disappearance or continuance of anecdotes as a genre and characterise the general tendencies in the tradition. Proceeding from the latter, the overview has also set a secondary goal to observe the changes in contents of the ethnic jokes over the past century. The observation will reveal whether and 
how changes have taken place in the Estonian ethnic humour, and the obtained information enables to hypothesise on the social, political and cognitive reasons for these changes (which, however, will not be elaborated further in this article).

In the initial stage of my research I had the impression that anecdotes - including ethnic anecdotes - are no longer told or invented. At social gatherings joke-telling sessions lasting for hours, where one topic led to another and inspired a new topic in turn, are no longer held. While in my master's thesis I discussed the topic cursorily, the present overview was prompted by this very impression, aiming to search for answers whether the tradition of anecdote-telling is disappearing or is in fact adapting to the demands of modern media, changed conversational norms, etc. and arguing that the present situation is a logical result of the changes which started already during the transformation of popular jokes into anecdotes.

Research material on the Estonian ethnic humour used in the study covers the period from the late nineteenth century to the present day. The material could be divided in three major groups:

(1) Folk humour of the earliest layer published in the final decades of the $19^{\text {th }}$ century in collections Rahva naljad ('Folk Humour') compiled and edited by Matthias Johann Eisen;

(2) Jokes mostly about the Soviet period created and published during the 1960s - the 1990s, from a collection of anecdotes compiled by Jüri Viikberg (published in 1997) and from the collection compiled by Luule Krikmann (collected in Tartu during 1965-1989; available at http://haldjas.folklore.ee / kriku /HUUMOR/soviet.htm);

(3) Anecdotes collected from the Estonian language Web pages (since 1996, retrospectively since the starting of Fidonet in 1990). This group is also the most numerous.

The temporal gap between the first and the second group is larger, but all other periods are evenly and quite representatively covered. The collections of Eisen are in this sense one-sided as his editing has resulted in a very idiosyncratic style. Eisen's personal preferences, however, should not affect the classification of characters, and this will be the main focus of analysis here. 


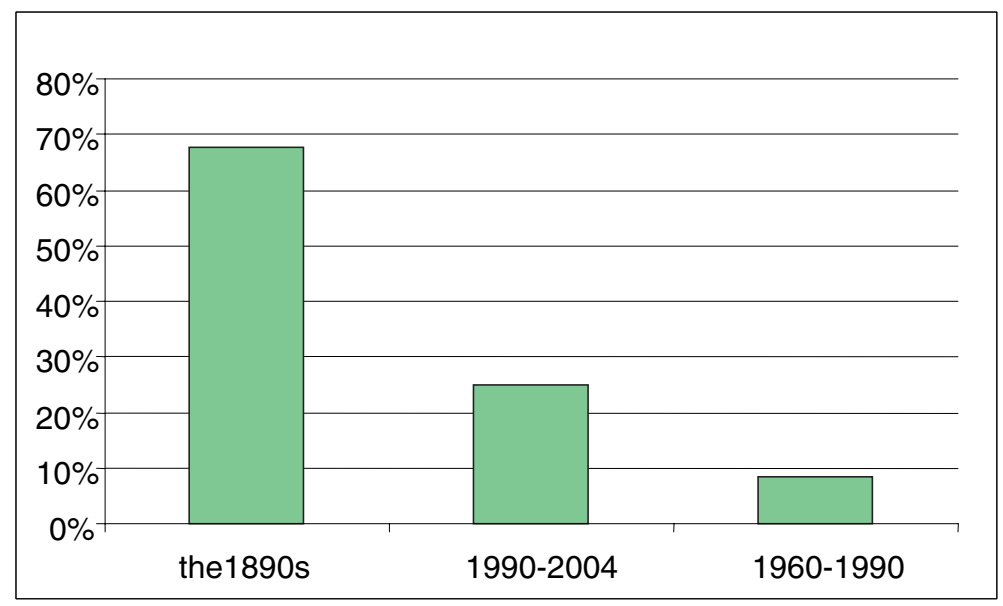

Figure 1. The proportion of ethnic jokes in Estonian humour during 1890 2004 (\%).

First I will provide a general description of the changes in the popularity of Estonian ethnic humour over the past century, relying on the proportion of ethnic jokes in all three major groups (Figure 1.).The figure shows that the proportion of ethnic specification in anecdotes has fallen considerably. The reasons why the popularity of ethnic anecdotes has decreased are merely speculative. In the $19^{\text {th }}$ century people lived in small closed communities, where everyone outside the limited community was "unfamiliar". In Postmodernist society the community boundaries are pushed as far as possible. Cross-cultural communication emphasises people's similarities rather than differences, therefore ethnic labelling becomes secondary also in anecdotes and gender specification (man/woman; name) is used instead.

A thorough study on Finnish wellerisms (Järviö-Nieminen 1959) from the period 1880-1955 points to the same tendency. The use of ethnic names is on the decrease and a person's occupation or simply gender becomes primary.

Thus, ethnic jokes are becoming increasingly less popular, but does this indicate to the disappearance of ethnic anecdote as a subcategory of the genre?

In order to answer this question I will observe the changes in anecdote types during the last two periods. Overlapping of anec- 
dote types in the first group and the last two groups is so marginal that it was excluded from further analysis (overlapping entailed only single types, the one with the most numerous variants was the anecdote type "Three Fat Germans"). Had the overlapping been more prominent it could be concluded that in addition to the drop in quantity there had also been a drop in quality in ethnic humour, where only old anecdote types are circulating and new ones are not invented. This would predict imminent and absolute disappearance of the anecdote tradition. The results are indicated on Figure 2:

Figure 2 reveals that the overlapping of anecdote types in these two periods is surprisingly small. Only 6 per cent of the entire material occurs during both periods (i.e. ca 100 types among the total of ca 1,200 types).

Thus, anecdotes are being reinvented and adapted under changed circumstances. In the following I will discuss the changes in contents of anecdotes.

The investigation of popular joke and anecdote characters over the three periods reveals four main groups of characters. A preliminary and more detailed analysis led to the following distinction: (1) kinsfolk, (2) inhabitants of the neighbouring countries, immigrants, (3) people sharing the same culture area (Europeans, Americans), and (4) representatives of exotic cultures (e.g.

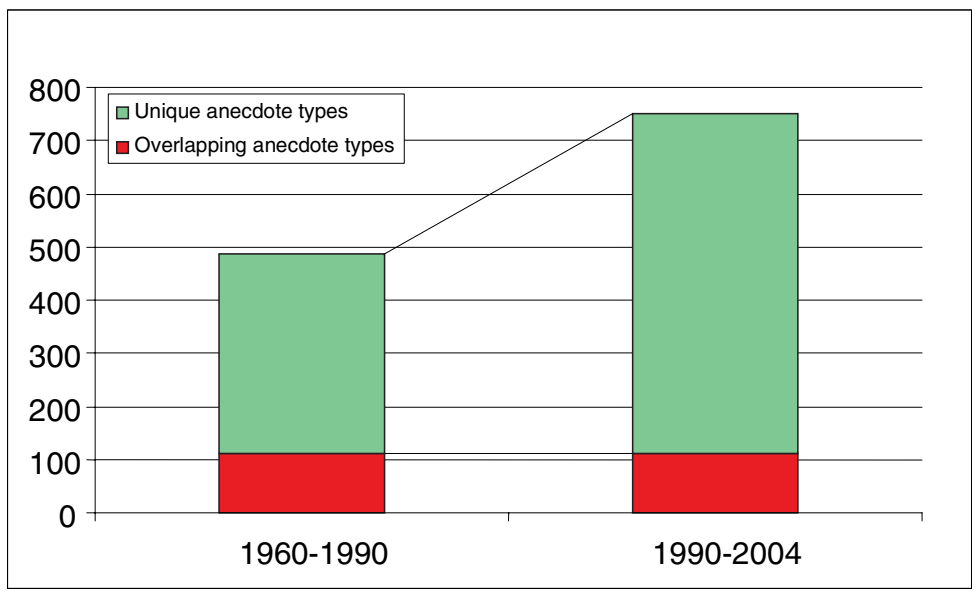

Figure 2. Overlapping of anecdote types over two periods (1960 - 1990 and 1991 - 2004). 


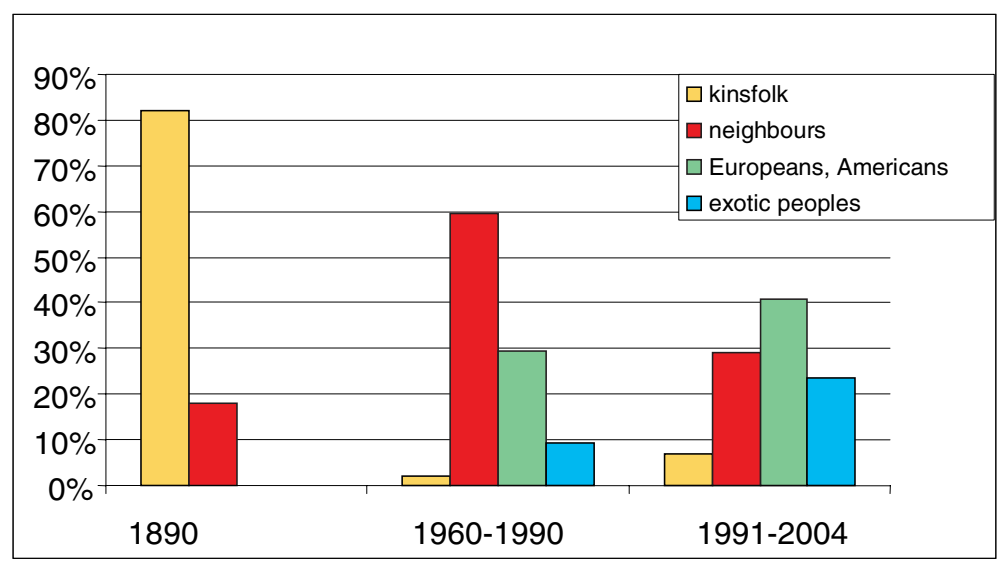

Figure 3. Classification of characters in Estonian ethnic humour during 1890 - 2004.

the Hindu, but also cannibals, etc.), which is the categorisation also used in the works by Christie Davies (1999).

Figure 3 shows that ethnic anecdotes have also undergone changes in contents.

Variability of characters is increasing to meet the demands of the society to constantly create new characters, which are, in turn, conditioned by the expansion of the cultural area. The growth of variability has been noted elsewhere (on Russian folklore see e.g. Shmelev \& Shmeleva 2002). The relationship between the geographical location and the chronological development of the anecdote tradition is by no means uniform. In Estonian humour jokes about the more distant neighbours in Europe and about the representatives of unfamiliar exotic cultures (e.g. the coloured people) emerged around the same time (although a small number of anecdotes about the coloured circulated already in the Soviet period). It can be assumed that the scheme corresponds to the chronological development of the anecdote tradition until the beginning of industrial-urban society and from then on no clear parallel can be drawn or synchronism detected between the temporal dimension and the growth in character variability. At the same time the diversification has happened, indicating to the active transformation of the anecdote tradition and its adaptation to the changed circumstances. 
In conclusion it may be said that the tradition of ethnic humour is not disappearing, even though the general decreasing tendency shown on Figure 1 clearly points to that. The anecdote culture is in fact undergoing a process of adaptation. Firstly, ethnic anecdotes no longer contain scripts (or stereotypes, which is a more understandable term) of local popularity and restricted potential of use, but universally applicable scripts like for example "stupid" versus "smart" or other basic binary oppositions are used instead. This also points to the wish to make fun of the ethnic groups, whose scripts are in fact not known. Secondly, the decrease in quantity can be partly explained by the fact that in the anecdote tradition of the newly independent Estonian republic political and ethnic anecdotes are clearly distinguishable and form two categories instead of the single category in the material collected during 1960-1990. New objects are actively sought for in jokes, as is evidenced by the growth in character variability over the three mentioned periods. Also, new channels of performance are constantly used - for example, oral joke-telling may soon be replaced by "virtual" joke-telling on interactive web sites for public commenting, such as the humour page of the Estonian news portal Delfi (Delfi Naljaleht, available at www.delfi.ee/jokes <http://www.delfi.ee/jokes >).

\section{Refernces}

Davies, Christie 1999. Change and Continuity in one of Europe's Oldest Comic Ethnic Scripts. Humor: International Journal of Humor Research $12(1)$, lk 1-31.

Delfi Naljaleht (www.delfi.eeljokes - 11. november 2004).

Eisen, Matthias Johann. Rahva Naljad. Matthias Johann Eiseni raamatud (http://www.folklore.ee/rl/pubtelee/vanad/eisen/index.html - 11. Nov. 2004).

Järviö-Nieminen, Iris 1959. Suomalaiset sanomukset. Suomalaisen Kirjallisuuden Seuran toimituksia 259. Helsinki: Suomalaisen Kirjallisuuden Seura.

Krikmann, Luule 1965-1989. Nõukogude-aegseid nalju Tartust (http:// haldjas.folklore.ee/ kriku/HUUMOR/soviet.htm - 11. Nov. 2004).

Laineste, Liisi 2004. Tegelased eesti etnilises huumoris. Magistritöö. Tartu: Tartu Ülikool.

Shmeleva \& Shmelev 2002. Russkii anekdot: tekst i rechevoi zhanr. Studia philologica: Series minor. Moscow: Jazyki slavianskoi kul'tury.

Viikberg, Jüri (koost) 1997. Anekdoodiraamat: Naeruga eilsest: Eesti anekdoot 1960-1990. Tallinn: Eesti Keele Sihtasutus. 